\title{
Individuální a kolektivní uvniłř spirituality New Age: terapeutické praktiky, tělesnost a intersubjektivita
}

\author{
The Individual and the Collective in New Age Spirituality: \\ Therapeutic Practices, Corporeality and Intersubjectivity \\ Hana Doležalová
}

\begin{abstract}
This article reports on a case study based on ethnographic research of New Age practices in a therapeutic centre in Brno. Attention is focused on the dichotomy between the individual and the collective, or the privatized and the shared in New Age religiosity. New Age is often described as a selfspirituality. The article deals with questions of how the self is conceived, what type of subjectivity and intersubjectivity is constructed by New Age practices and what kind of a "lived body" is formed by the employment of self-cultivation techniques. The process of reconstruction of identity and retelling the narrative about oneself during the therapy is examined. This new identity is enacted within a community, because it has to be confirmed by others. The social implications of the model of the body, on which such therapeutic practices are based, are explored.
\end{abstract}

KEY WORDS body, individualized religion, intersubjectivity, New Age, therapy

\section{New Age v kontextu soudobé náboženské situace}

Oblast náboženství je v současné době stále méně regulována. Těžiště se posouvá od byrokratických organizací opírajících se o stát k sítím skupinek a shromáždění, a k jednotlivcům, kteří hledají „,vlastní smysluplnou cestu“ (Lyon 2002). Stat’ se zaměřuje právě na tuto mnohotvárnou religiozitu, pro kterou je charakteristický důraz na vlastní volbu jedinců experimentujících v prostředí náboženské diverzity (Davie 2007).

Typickým př́ikladem toho, co bývá označováno jako individualizovaná religiozita, je spiritualita New Age. ${ }^{1}$ Vyznačuje se synkretickým čerpáním z mnoha náboženských tradic

Sociální studia. Fakulta sociálních studií Masarykovy univerzity, 3-4/2008. S. 103-119. ISSN 1214-813X.

Používám tento pojem, protože je k označení tohoto typu religiozity mezinárodně užíván v akademickém prostředí. V České republice ho samotní praktikující používají zřídka. Ti většinou nechtějí svou víru označovat jmény, případně mluví o „duchovní cestě“, „duchovních praktikách“ a podobně. Pro některé je spojen pojem „New Age“ s negativními konotacemi - implikuje př́liš zkomercializovanou spiritualitu. Jiní ho ani neznají. Pojmem New Age bývá označován velice široký proud praktik a představ, které se navíc do určité míry prrekrývají s tím, co bývá označováno jako „hnutí lidských potenci““ nebo „neopaganismus“ (Lužný 1997, Heelas 1996). Bloch (1988) užívá pojmy „alternativni “ či „,kontrakulturní spiritualita“. Pro konkrétní přehled několika rysů, které tyto rozmanité fenomény spojují - tedy hlavních „principư“, na kterých New Age praktiky stojí, viz Hanegraaff (1996). 
i nenáboženských systémů. Strukturu New Age lépe vystihuje pojetí sítě² složené z komunit, center, seminářů, festivalů, obchodů, škol, skupinek, vztahů dvojic (např́ílad léčitel-klient) i jednotlivců (Heelas 1996). Všechny spojuje určitá náboženská či světonázorová orientace, ale jasně definovaná nauka nebo praxe zde chybí (Lužný 1997).

Jedním z rysů, který u New Age praktik nacházíme, je usilování o radikální osobní i kolektivní transformaci. „Probuzení potenciálních schopností lidského já - psychických sil a schopnosti fyzického či psychického léčení má být odrazovým můstkem masivní proměny kolektivního vědomí“ (York 1995: 39). S transformací souvisí také oblast léčení spojená s důrazem na holistický př́stup. Proces léčení má zahrnovat nejen jedincovo směřování k zážitkům vlastní jednoty, ale má se dotýkat i Země a jejího znečištění, pracovního prostředí a rozvíjení kreativity, a tak dále (Heelas 1996).

New Age semináře, kurzy, workshopy a individuální terapie zahrnující nejrůznější typy léčení představují rozsáhlou oblast terapeutické kultury, která je spojena se zájmem západní společnosti o tělo a zdraví. Tělo se stalo reflexivním projektem, tělesnými praktikami vyjadřujeme naši identitu (Giddens 1991). Žijeme v „,somatické společnosti“ a hledání smyslu se přesunulo do sféry vlastního já a těla (Turner 1996). „Tělo a tělesnost jsou svojí zakořeněností v každodennosti a svým propojením se smyslovým prožíváním nejbližším a nejpřirozenějším nástrojem vyjádření vztahu $\mathrm{k}$ sociálnímu okolí. Je to totiž tělo, které je vhodným prostředkem pro vyjádření a vytvoření identity, jejíž součástí je vnímání stejnosti a vyjádření odlišnosti“ (Václavík 2005: 159).

\section{Komunita nebo privatizovaná religiozita?}

New Age je charakterizováno zajímavými paradoxy. Přestože jsou zde praktikující jen volně seskupeni, považují se často za komunitu. Systém věr je vysoce personalizovaný, přesto je tu silný smysl pro sociální solidaritu. Odpověd’ na otázku, čemu věrit, má člověk hledat uvnitř svého nitra, přesto jsou mnohé normy a představy sdíleny s ostatními (Bloch 1988). Zajímá mě, jak je toto spojení privatizovaného a sdíleného v praxi možné. Sleduji terapeutický proces tak, jak jím praktikující New Age spirituality procházejí a vyprávějí o něm.

Soustředím se na proměny identit v průběhu terapií, kdy dochází k rekonstrukci vyprávění o sobě samém. To se děje v prostředí komunit, protože okolí musí novou identitu v procesu určitého vyjednávání potvrdit. Identita není nic daného, je třeba ji vytvářet skrze reflexivní aktivity jedince (Giddens 1991). Jáství je utvářeno akty sebe-interpretace. „[I]dentita neexistuje sama o sobě, vždy musí být vytvářena. $V$ tomto pohledu pak identita jako typifikační schéma není ničím jiným než formou vědění produkovanou akty označování, jejíž formování může být interpretováno analogicky vzhledem k budování jiných forem významu“ (Szaló 2003: 15-16).

Mnohé terapeutické techniky pracují s tělem. Kladu si otázku, jak jsou těla těmito praktikami utvářena $\mathrm{v}$ každodenním životě návštěvníků centra. Způsob, jakým je vnímáno vlastní tělo a jak je s ním nakládáno, je důležitou součástí sebepojetí i formování vztahu k okolí. Při zkou-

2 Např́ílad podle Lyona (1993) tento pojem lépe odráží obrovské množství praktik, které sem spadají. 
mání sebekultivačních technik se mohou ukázat konceptuální základy eurocentrické epistemologie jako nedostačující (Ozawa-De Silva 2002). Předkládám proto v textu určité modely tělesnosti, které umožňují lépe porozumět nazírání těla v New Age.

\section{Případ Zlatého klíčku}

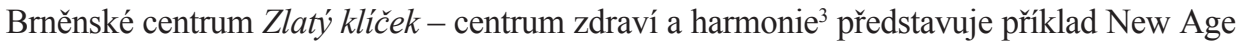
spirituality. Zde jsem prováděla etnografický výzkum. Šlo mi o porozumění světa tohoto centra - aktivitám, které zde probíhají, a významům, které jim lidé přikládají. Použitou metodu představovalo to, co Geertz nazývá ,zhuštěným popisem“. Ten má objasňovat důležitost událostí, hledat odpověd' na to, co je jejich prostřednictvím sdělováno, jaký mají pro jednající význam (Geertz 2000). Zaměřila jsem se na výpovědi uvnitř skupiny návštěvníkủ Zlatého kličku, přičemž mi šlo o to ukázat, jakým způsobem činí svůj svět smysluplným. V textu se snažím představit prostředí centra a srozumitelně přeložit jazyk mých informantů čtenáři.

Zúčastněné pozorování trvalo $\mathrm{s}$ krátkodobými přestávkami dva roky (od jara 2005 do jara 2007). Získat přistup do Zlatého klíčku nebylo nikterak složité, začala jsem navštěvovat přednášky a semináře, které zde probíhaly, a navazovala jsem první kontakty s terapeuty i dalšími účastníky. Statut nováčka $\mathrm{v}$ cizím prostředí $\mathrm{v}$ počátcích zúčastněného pozorování byl pro mě jako výzkumnici výhodný: mohla jsem klást mnoho otázek a má zvídavost nepůsobila nepatřičně.

Zkoumala jsem aktivity, které zde probíhají - individuální i skupinové terapie, kurzy, přednášky a další. Při jejich výběru jsem usilovala o zachycení rozmanitosti jednotlivých typů technik, jako jsou např́íklad meditace, poradenství osobního růstu, techniky pracující s energií těla, dietetické poradenství, diagnostické techniky, zdravá výživa, fyzická cvičení, masáže, regresní metody a podobně. $V$ tomto centru nabízí své služby čtrnáct terapeutek a terapeutů, kromě jejich pracoven se zde nachází prodejna zdravé výživy, prŕrodní kosmetiky, knih atd.

Jako výzkumnici mě zajímalo, jak jsou věci dělány v praxi, protože „vztahy mezi objekty nejsou schovány v řádu věcí, ale ustavovány v komplexních praktikách“ (Mol 2002: 150). Neomezovala jsem se jen na to, co se rríká, tedy na postoje, názory a představy, protože zejména praktiky jsou tím efektivním nástrojem změny prožívání tělesnosti, sebe sama a okolí.

Dále jsem prováděla polostrukturované rozhovory s lidmi účastnícími se různých akcí v centru. Několika lidem - těm, se kterými jsem se už znala lépe - jsem se zmínila o svém záměru „psát o Zlatém klíčku práci ve škole“. Reagovali většinou se zájmem a vyjádřili ochotu zodpovědět mé otázky. Považovali to za prŕnosné: podle svých slov si během rozhovoru mohli uvědomit nové souvislosti a ujasňovat si dále svůj náhled na svět, rozhovor vnímali jako určitou formou sebepoznávání, seberozvíjení či vzájemného obohacování se. Důvěra vedoucí k určité otevřenosti ke mně a ochota věnovat čas rozhovoru byly zřejmě výsledkem jejich uznání mnou investovaného úsilí, díky kterému jsem se stala součástí této sítě známých či prátel. Terapeutky,

Viz http://www.zlatyklicek.cz/. „Klíček“ odkazuje na symbol klíče k odemčení brány do vlastního nitra nebo klíčící rostliny evokující osobní růst. Analýza tohoto prostoru nabitého náboženskými významy viz Doležalová (2007: 16-18). 
pro které jsem byla novou, neznámou tváří, a ty, se kterými jsem nebyla delší dobu v kontaktu, požadovali za rozhovor peníze (jako za kteroukoli jinou konzultaci).

Zaměřila jsem se především na pravidelné návštěvníky centra - na ty, kteří se opakovaně účastní zde pořádaných akcí. Systém věr a praktiky, se kterými se ve Zlatém kličku setkali, stejně jako zdejší sít' známostí, do které nyní patří, se staly součástí jejich každodennosti. Dále jsem oslovila jedince, které do Zlatého klíčku přivedla snaha řešit své problémy formou individuální terapie, ačkoli jinak s tímto typem praktik do kontaktu často nepřicházejí. Rozhovor jsem provedla také s terapeutkou, která Zlatý klíček opustila a založila centrum vlastní. Její pozice nabízí zajímavou perspektivu člověka, který byl v centru dění a dnes je již ,outsiderem“.

Celkově jsem se ptala dvanácti lidí, osmi žen a čtyř mužů. Převaha žen je všeobecným rysem Zlatého kličku - jak mezi terapeuty, tak mezi klienty. Interview trvala od půl hodiny do dvou hodin, byla nahrávána na diktafon a poté přepsána. V průběhu rozhovorů jsem musela reagovat na okolnosti, jako byl dostupný čas a ochota komunikačních partnerů povídat. Připravila jsem témata, ke kterým jsem se chtěla postupně dostat. Některé respondenty jsem nechala, aby vypravovali spíše sami, protože mluvili o tom, co považovali za důležité a co zároveň souviselo bezprostředně s mým tématem.

Zdroje dat tvoří tedy kromě rozhovorů mé vlastní písemné poznámky z kurzů a přednášek, přepsané nahrávky meditací, jedné terapie, jednoho kurzu cvičení, rozhovoru s masérkou Zlatého kličku v rádiu, dále webové stránky centra a terapeutky, která Zlatý kliček opustila a vytvorrila centrum vlastní. Studovala jsem také New Age literaturu zabývající se tematikou nemocí a léčení, která je mnohým terapeutům i jejich klientům známá.

Velkou pomocí mi byl počítačový program Atlas-ti, ve kterém jsem pracovala s přepisy rozhovorů, se záznamy meditace, kurzu a terapie. „Zatrhávala“ jsem zajímavé úryvky a psala si k nim komentáře. Podle opakujících se témat jsem vytvořila kódy a ty pak k úryvkům přiřazovala. Jako přínosné se ukázalo kódování vlastních komentářů a poznámek. Nemusela jsem držet souvislosti v hlavě: postupné zatrhávání, přiřazování a spojování je umožňuje vidět (Konopásek 2005).

\section{Péče o sebe: egoismus a solidarita}

Sociální teoretik M. Maffesoli v New Age vidí vyjádření obecnějších tendencí dnešní doby: „[P]řres rozličné tělesné i duchovní fenomény současného New Age můžeme pozorovat nepotlačitelný vitalismus současného nomádství, zdůrazňujícího instituující aspekt věcí“ (Maffesoli 2002: 79). Používá metaforu bloudění k vyjádření současné touhy po jinde, která v sobě obsahuje aspekt dobrodružství a také riziko rozvrácení zavedených jistot a myšlenkových konformismů. Tulák neusiluje o svobodu jednotlivce, nýbrž o mystickou „zkušenost s bytím“, kdy člověk prožívá jakési vystoupení ze sebe sama. „Bludný život je ze všeho nejméně životem individuálním“ (Maffesoli 2002: 148). Bloudění a stavy extáze dovolující uniknout uzavřenosti individuálního času tedy znamenají osvobození. Dochází totiž k vyvázání se z typizovaných identit formovaných zabezpečovacími institucemi, jako jsou rodina či profesionální kariéra. Typizovanou identitu vidí Maffesoli jako vězení zabírající prostor četným potencialitám, jež se v rámci totální realizace vlastního já nabízejí. Nevyhraněná identita 
pomáhá jedinci rozšriřit své pole činností, zvětšuje jeho možnosti (Maffesoli 1994). Jedinec má možnost nalézt širší já.

Tento autor v současném světovém dění rozpoznává obecnějšś vzorce, ${ }^{4}$ určité nadčasové struktury opakující se $\mathrm{v}$ dějinách, a všímá si i tendencí $\mathrm{k}$ solidaritě, touze vstupovat do souvstažnosti s druhými a se světem a požadavku po harmoničtějším spolubytí. Figura Dionýsa, charakteristická pro současné období, podle něj totiž solidaritu implikuje. Slast není nutné vždy chápat jako projev egoismu. Tam, kde jiní vidí individualismus, Maffesoli rozpoznává formy kolektivismu (MacLean 2000).

Sociologové a religionisté často akcentují při výčtu charakteristických rysů New Age zaměření se na vlastní já (například Heelasův (1996) koncept „self-spirituality“, který mnozí přejímají). Tento důraz vede u některých $\mathrm{k}$ interpretování New Age praktik, např́klad terapií, jako kultury narcismu (Johnston, Barcan 2006). New Age bývá kritizováno jako individualistické až solipsistické. Podle Hanegraaffa tvoří symbolismus vlastního já jádro tohoto hnutí, což prakticky znemožňuje, aby fungovalo jako náboženská kolektivita (Hanegraaff 1999: 155). Domnívám se, že je v této debatě klíčové si ujasnit, jak je já pojímáno. Extrémní zaměření se na sebe, které v New Age nacházíme, může být interpretováno různými způsoby záleží na tom, o jaký koncept subjektu se jedná.

Tento obrat $\mathrm{k}$ vlastnímu já jsem pozorovala i v brněnském centru. Na semináŕích, přednáškách či v průběhu terapií je zdůrazňováno, že jedinou autoritou, na kterou se lze spolehnout, je vlastní vnitřní hlas. Jen ten správně radí, čemu věřit. Podle terapeutek nelze něco prrijímat jen proto, že to někdo říká nebo že je to někde napsáno: své klienty vybízejí, aby se opírali o vlastní zkušenost. ${ }^{5}$ Pokud je pro některé návštěvníky centra autoritou Bůh, jedná se spíše o hlas z hlubin nitra, ne např́klad o Boha definovaného církví. Ani terapeut zde nemá být tím, kdo by rozhodoval o životě svého klienta a bral za něj na sebe zodpovědnost. Terapeuti zdůrazňují, že jejich role spočívá $\mathrm{v}$ tom, že pomáhají klientovi navázat kontakt se sebou samým, naučit ho být k sobě vnímavý a stát se svým vlastním učitelem. Tento prístup vyjadřuje mladá žena navštěvující meditace s anděly, kurzy kreslení mandal ${ }^{6}$ a terapie kineziologickou metodou ${ }^{7}$ takto:

Tyto vzorce souvisejí se dvěma principy, které Maffesoli popisuje metaforicky pomocí figur Apollóna a Dionýsa. Tato myšlenka dvou rozdílných pudů pochází od Nietzscheho. Dionýsos je tajemné božstvo charakterizované stavem opojení a mystickým odosobněním. „[P]robouzejí se ona dionýská hnutí, za jejichž ponenáhlého vzrůstu vše subjektivní mizí a mizí, až docela se ztratí v sebezapomnění. (...) Zpívaje a křepče projevuje se člověk článkem vyšší jakési pospolitosti“ (Nietzsche 1923: 26).

5 Podobně píše Heelas (1996): Dogmata náboženských tradic, rodiče, vědci, duchovní vůdcové, ti všichni se mohou mýlit. „Pravdy“, které nabízejí, musejí být podle New Age spirituality zprostředkovány vlastní zkušeností.

6 „Mandala“ znamená v sanskrtu „kruh“. Vytváření mandal - kruhovitých kreseb, maleb či sypaných obrazců, je meditační technika užívaná zejména v buddhismu. Ve Zlatém kličku jsou nakopírované šablony mandal vykreslovány barevnými pastelkami. Dokončené obrázky nakonec terapeutka použije k ,diagnostickým“ účelům: ,čte“ z informace o jejich autorovi. Probíhají tak krátké individuální terapeutické rozhovory odehrávající se před celou skupinou př́tomných lidí.

7 Kineziologie je metoda usilující o ideální fungování ,jednotného mozku“ (One Brain), kdy pravá a levá hemisféra mezi sebou harmonicky spolupracují. 
Kde hledat řešení? V sobě, tam jsou všechny odpovědi. Jednodušší je dívat se ven kolem sebe, šplhat někde na Mount Everest a mít pocit, že tam nahoře ti to někdo poví, ale nosíš to stále v sobě.

Podle návštěvníků centra je potřeba navázat kontakt s vlastním hlubším já a neopírat se o různé prekoncepce vytvořené na základě toho, co je přejato z okolí. Podle terapeutů ví každý člověk někde uvnitř víc, než si myslí.

Spiritualita New Age rozlišuje „pravé jác“ a „,vnější pomíjivou osobnost““ neboli „ego“ (Heelas 1993). Brněnská terapeutka používá k postihnutí tohoto já, které není totožné s egem, pojem „duch“:

Duchovní cesta znamená, že chci jít do toho hlubšího nitra za to ego. (...) Podle mě tu duchovní cestu děláme proto, abychom se co nejvíc nechali vést tím duchem. (...) Pokora, oddanost k něčemu uvnitř. Vždycky si vzpomínám, co byl vlastně můj záměr, proč jsem se do toho dala, proč jsem do toho šla. Když jsem si uvědomila, že toto je to, co vzniklo z té hloubky, začalo mě to najednou naplňovat silou.

Společným rysem výpovědí informantů centra je vysoká míra sebereflexivity. Zamýšlejí se nad tím, k čemu vlastně techniky v jejich životě vedou. Kladou si otázku, zda opravdu dochází ke kýžené osobní proměně, nebo je terapie jen příležitostí, jak se jí naopak rafinovaně vyhnout a pouze podpořit vlastní samolibost a sobeckost.

Podle terapeutky, která provádí kraniosakrální ošetření, ${ }^{8}$ barevnou terapii aura-somu, ${ }^{9}$ vede kurzy různých typů meditací a jiné, může být duchovní cesta, tedy snaha o sebepoznání, „pastí“ v tom smyslu, že může posilovat ego člověka. Při své práci pozoruje, jaké jsou efekty sebepoznávacích a seberozvíjecích praktik. Podle její zkušenosti nutí člověka konfrontovat se, i v prrípadě, že nechce, s vlastními postoji. Techniky samotné mají tedy podle ní sebekonfrontační povahu.

Bohužel, co tu cestu procházím, řekla bych, že sebekultivační techniky ego hodně podporují. (...) Spousta lidí je může dělat jen na oko, maskuje tím útěk před tím. Ale zaplat' pánbůh, energie je vyšší a my se s tím stejně zkonfrontujeme, my se tomu ještě v životě budeme muset postavit, protože my jsme tu energii rozhýbali. Už jsme ji vytáhli, dali jsme jí život, aby se realizovala, už jsme ji dali do pohybu a ona nás do té situace postaví.

Proměnu vnímání sebe sama a vlastního vztahu k okolí popisují návštěvníci jako výsledek mnoha drobných zkušeností, které člověk praktikováním technik získává. Některé jsou líčeny jako intenzivní extatický stav, jakýsi „transpersonální“ zážitek rozšířené identi-

8 Kraniosakrální terapie je technika přikládání rukou, která má napravovat nevyváženosti „kraniosakrálního systému“. Podle slov terapeutky je to velmi jemná masáž, fyzicky téměř nevnímatelná, která má za cíl zharmonizovat horní a spodní část těla a zlepšit spolupráci vědomí a těla.

9 Technika pracující s dvoubarevnými lahvičkami (jedná se tedy také o terapii barvami) s olejem a vodou obsahující výtažky z rostlin, energie drahokamů, minerálů a barev. Tato emulze se aplikuje na určitá místa na těle a má působit na energetický systém člověka a léčit nemoci projevující se na těle, v emocích, vlastnostech či chování. 
fikace, jindy se podle výpovědí jedná o pozvolný proces. Klient a zároveň bývalý instruktor čchi-kungu ${ }^{10}$ ve Zlatém klíčku hovoří o své zkušenosti:

Čím víc se stáváš jedinečným, tím víc možná chápeš propojenost s celkem. (...) Protože čím víc se snažím pochopit sám sebe, kdo jsem - což je to nejtěžší, co můžeš studovat - tím víc chápu celek. Když pochopíš, co se v tobě děje, pak pochopíš druhé, proč dělají to, co dělají. Zjistíš, že jednáš velmi podobně, nebereš to tak, že ten člověk je někdo jiný, jste součástí toho druhého, jste jedno, podstata je stejná. Když to vezmu u sebe, určitě to tak mám se svými rodiči.

Jak vyplynulo z rozhovoru, zlepšení vztahů s rodiči si tento muž vysvětluje jako důsledek sebepřijetí.

\section{Jedinec a komunita}

Podle Tuckera (2002) jsou v prostředí New Age spirituality rodina, komunita či společnost vnímány jako omezující osobní růst. „Náprava vlastního já s sebou většinou nese odmítnutí širšího sociálního světa“ (Tucker 2002: 47). New Age se podle něj liší od tradičních náboženství tím, že lidi neváže k větší skupině. Toto tvrzení se však zdá v kontextu výzkumu v brněnském centru přinejmenším zjednodušující. Terapeuti usilují prostřednictvím práce se svými klienty o proměnu způsobů, jakými fungují rodiny i větší komunity. Takto se vyjádřila jedna $\mathrm{z}$ nich:

Můj záměr byl pracovat na transformaci vědomí, s lidmi, kteří ve svém životě chtějí dělat zásadní změny. Chtěla jsem působit na systém společnosti. Měla jsem pocit, že bych měla jít do nejzazších buněk, do rodin a do vztahů.

Vidíme, že mluví o transformaci v souvislosti s rodinami a vztahy. Chce působit na společenský systém, nejde jí jen o spokojené jednotlivce.

Návštěvníci centra hovořili v rozhovoru o tom, že cítí, že všude po světě jsou lidé, kteří také jako oni „na sobě pracuji““:

Myslím, že se v současné době o tyto věci začíná zajímat víc lidí. (...) Duchovní sféry nám posílají světlo, které nás má dostat na vyšší vibrace. Lidé se dostávají na vyšší stupeň uvědomování si sebe sama.

Po jedné z meditací děkuje terapeutka lidem, kteří se jejích akcí neúčastní, ale „rozvíjí hloubku ve svých životech“. To je to, co je podle ní spojuje, at’ už se znají nebo ne. Jde jim o to samé - usilují o změny a spolu, ačkoli zvlášt', je chtějí provádět. Podobně Heelas (1996) píše o v prostředí New Age rozšířené představě, že jednotlivci, kteří například meditují, přispívají $\mathrm{k}$ větší míře štěstí a míru ve světě. Vlastní duchovní aktivity zasazují návštěvníci centra do širšího kontextu kolektivních snah části lidské populace o proměnu situace na Zemi.

10 Soubor tělesných a duševních cvičení, jejichž cílem je harmonizace energie v těle (doslova znamená „práce s energii“"). Jedná se o velmi staré cvičení, které je součástí klasické čínské medicíny. 
Existence takovéto New Age „představované komunity“11 je umožněna také novými komunikačními technologiemi, rychlým šířením obrazů a symbolů prostřednictvím elektronických médií všeho druhu (Lyon 2002).

Důležití jsou také lidé, kteří jsou bezprostředně fyzicky přítomní v okolí. Stávají se referenční skupinou, vůči níž je poměřováno vlastní chování. Jedna z návštěvnic centra se při studijním pobytu v Pař́ži ocitla mezi lidmi s jiným životním stylem, než byla zvyklá:

Když se všichni bavili, já jsem se tak nebavila, protože alkohol přece nepiju, žádné omamné látky nepozřu. Takže jsem tam vypadala divně, všichni erasmáci pili a já ne, ještě jeden kluk s turbanem na hlavě nepil. Byli jsme taková exotická dvojice [smích]. Pak jsem se sekla, opila jsem se tam, a najednou všechno přestalo. (...) mám plné zuby těch vegetariánských blbostí. Kašlu na vás všechny.

Nyní je zpět v Brně, ve svém prostředí, mezi přáteli, kde je normální například jíst podle speciální diety, a zase „objevuje své původní nadšeni““.

Okolí hraje důležitou roli, protože ono musí identitu akceptovat a potvrdit, jemu musí být vlastní sebepojetí prezentováno. To je to, co lidé ve Zlatém klíčku pak vyjádří slovy: „tam mi rozumí“ nebo „mohu být sama sebou“, což je umožněno sdílením určitého symbolického univerza, které dává řád subjektivnímu chápání životní zkušenosti. „Identita je s konečnou platností legitimizována svým zařazením do kontextu symbolického světa“ (Berger, Luckmann 1999: 101). Zlatý kliček tak nabízí určité sdílené struktury věrohodnosti, díky nimž je určitá definice situace či vlastní identita srozumitelná (Berger, Luckmann 1999). Někdy okolí tyto aktivity nechápe. Pak někteří návštěvníci centra, než aby se cítili ve společnosti takto odlišných lidí nepř́ijemně, raději hledají nové přátele. Je zajímavé, že s tématem proměny okruhu lidí ve vlastním okolí jsem se setkávala v centru poměrně často a popisuje ho i jedna z inspiračních karet $^{12}$ : „Okruh vašich přátel a známých začíná mít vyšší frekvenci. Staří přátelé se možná ubírají jinou cestou a do vašeho života přicházejí noví lidé. Vaše měnící se zájmy a priority rozčeřily vody vašeho života ve všech směrech. (...) Víly vás vybízejí, at’ se těchto přirozených změn ve svém životě nebojíte. Vždyt' své staré prrátele nezavrhujete ani neodsuzujete. (...) Vězte, že si zasloužíte skvělé přátele, kteří vás inspirují, podporují, kteří vám rozumí a doplňují vás“ (Virtue 2003: 30-31). Pro sebepojetí, které vzniká v interakci, mají primární skupiny zásadní význam a New Age spiritualita není výjimkou.

Majitelka centra říká, že Zlatý kliček založila hlavně jako místo setkávání, kde lidé, kteří o sobě neví, ale tuší, že existují, mohou vytvářet sít' známostí.

Vytvořit místo, kde by se mohli setkávat lidé, kteři jsou svým způsobem stejně zaměření, ale odlišní od normální běžné společnosti, kteří se třeba cítí sami a mají pocit, že jim nikdo podobný v okolí není. A každý z nás, co je tady, jsme prošli tímto obdobím a nakonec jsme se potkali, takže víme, že nás je spousta, jenom jsme nevěděli, kde se sejít. (...) To znamená, že přijdou, dají si třeba čajíček

11 „Imagined community“ (Anderson 2003).

12 Karty slouži k výkladu budoucnosti nebo současného stavu člověka. Mají pomoci porozumět „poselství“, které daná situace přináší, nabídnout návod řešení problému a podobně. Mnohé terapeutky s kartami pracují, je také možné je zakoupit v místní prodejně. 
a ví, že tady bude někdo, s kým si budou moct popovídat, když ho neznají. Budou vědět, že když je tady, že je zhruba na stejné cestě jako oni.

Vytvoření Zlatého kličku a způsob jeho fungování tedy představuje jakousi snahu působit proti individualizačním tendencím, které způsobují, že pro lidi s podobnými problémy, postoji či hodnotami není snadné se najít.

\section{Extáze a rekonstrukce identity}

Cílem terapeutických technik má být poznat svazující představy o sobě samém a na chvíli z této ,železné klece“ návodů na vlastní projev vystoupit a zažít se (ve vztahu ke svému okolí) jinak.

Maffesoli (1996) používá pro stav, kdy si nejsme vědomi sami sebe, pojem „extáze“.13 V průběhu meditací, hraní na tibetské misky, v tvořivém procesu kreslení mandal, při koncentraci na tělesné cviky a energii v těle, a tak dále, dochází často k těmto momentům, které prožívají př́ítomní společně. Maffesoli (1994) zdůrazňuje důležitost zkušenosti spolubytí, blízkosti prožité zkušenosti, „citové formy sociálního života“ (Maffesoli 1994: 28). Muž, který se zúčastnil týdenního pobytu v přírodě pořádaného dnes už bývalou terapeutkou Zlatého kličku, popisuje jednu z aktivit, ze kterých se skládal program - takzvanou kundalini ${ }^{14}$ meditaci. Přirovnává svou zkušenost k jiným „strategiím“ dosažení transu - zapomenutím sebe sama: elektronické hudbě, stroboskopu, drogám, bubnování.

Pustí se taková spešl hudba, k tomu určená, zaujme se nějaká vhodná poloha (asi jako na koncertě, když se jde na něco hrozit) a 15 minut se člověk třepe pěkně v rytmu a uvolňuje se a uvolňuje a dostává se hloubš a hloubš. Pak se dalších 15 minut hudba změní v taneční (ovšem nesmí si někdo myslet, že taneční je od slova techno nebo rave nebo jinej podobnej blud :-) ). Spíš bych to přirovnal $\mathrm{k}$ Sepultuře a jejich brazilskejm tanečkům, $\mathrm{k}$ indiánům křepčícím kolem ohně a totemů a nebo (což mě přišlo hodně výstižný) $\mathrm{k}$ jemně sjetejm, $\mathrm{v}$ tranzu řádícím máničkám na koncertě Jima Morrisona. (...) Trošku mi to taky připomnělo moje exkurze ze zvědavosti, kdy sem na rockovejch fest'ákách vyhledával ty zapařený techno stany s desítkou stroboskopů umístěnejch na metru čtverečním a davama nepř́itomnejch tanečníků, který se dokázali i několik hodin divoce zmítat v rytmu samplů a automatickejch bubeníků. (...). Svým způsobem mě to vždycky fascinovalo, i když sem ty lidi nikdy nepochopil, čistý to nemohli vydržet... A ted' sem si zrovna tak připadal já sám. Ovšem bez alkoholu a bez drog.

(http://sofielairena.sblog.cz)

Maffesoli (1994) tematizuje emoce a iracionalitu jako klíčové prvky identity. Extáze, kterou může být třeba náboženský prožitek, může být plánována, proživána a nakonec je o ní vyprávěno. Mladý muž, který využil v době své partnerské krize ve Zlatém klíčku poradenské služby pomocí techniky ,automatické kresby““, ${ }^{15}$ se svými přáteli už pravidelně tráví

13 „Ex-stasis“ - „exit from the self“ jako „vykročení ze sebe sama“ (Maffesoli 1996: 19).

14 Energie jinak nazývaná „hadí síla“, která „dř́íme“ v oblasti kostrče a může být probuzena určitými technikami (ale probouzí se i samovolně). Původně byly představy o kundalini součástí jógy.

15 Automatická kresba je kresba provedená tak, že ruku neřídí myšlení, nýbrž intuice. Taková kresba může mít účel diagnostický či léčebný. V centru probíhají kurzy automatické kresby a některé terapeutky ji využívají při své práci. 
víkendové noci v lese, kde podle svých slov praktikuje šamanismus. Zeptala jsem se ho, co tím myslí:

Šamanismus, to je oheň a př́roda, houbičky, bubny, trans a osvobození duše od těla. Ego přestane do všeho kafrat a člověk si užívá, co je přirozené, svobodu. Přirozené vědomí.

Maffesoli (1994) jako významné prvky sociálního života zdůrazňuje výměnu a dialog, které nemusí být verbalizovány. Dynamická meditace nebo bubnování jsou společnými aktivitami přinášejícími prožitek kolektivu.

\section{Relační typ já}

Zájem o ekologická témata, ${ }^{16}$ o vyřešení vztahů v rodině a podobně, souvisí s tím, že já je pojímáno jako mnohem širší entita než já ohraničené vlastním tělem, majetkem či nejbližšími lidmi v okolí. Jeden z centrálních principů New Age, podle kterého „vše souvisí se vším“, a zákon karmy, který říká, že každá akce vyvolá odpovídající reakci, vybízí k širší zodpovědnosti - nejen za sebe, ale za široké okolí, za celou planetu. Hranice vlastního ,jác je tak pomyslně posunuta. Individuální i skupinové terapie přinášejí určité prožitky, které jsou zde společně interpretovány. Po meditaci, cvičení a dalších aktivitách často přichází na řadu „sdílení vlastních dojmů“. Tato část hraje velkou roli v tom, do jakého kontextu bude vlastní zkušenost zasazena. Do velké míry tento rámec utváří terapeutka, která vybízí přítomné k tomu, aby řekli ostatním o svém prožitku, a postupně skládá z jednotlivých výpovědí celistvější ,„příběh“. Například příběh o kolektivním léčení válečných traumat.

Proto i vy, kdo chcete vykonat něco pro dny v míru a radosti, můžete se zapojit individuálně do duchovního čištění a pomoci tak nejen sobě, ale i druhým na tomto světě... Nechte prosím toto světlo proudit skrze vás, aniž byste jej jakkoli ovlivňovali a cokoli po něm chtěli...

Terapeutka komentuje meditaci s archandělem: lidé přišli čistit své nitro od svých starých bolestí, ale zároveň tak pomáhají celé planetě - přítomným lidem je v meditaci ukázáno, že Země stále vyzařuje do vesmíru energii války a bojechtivosti a že všichni lidé nesou v sobě následky válečných konfliktů. Účastníci po skončení meditace říkají, že při ní sdíleli smutek a pocit’ovali soucit se všemi, kteří války prožili. Podle svých slov přišli na to, že smutek uvnitř nich není jen jejich smutkem.

New Age hlásá nutnost osobní proměny i celkové kulturní a sociální změny. Lužný v této souvislosti používá koncept „,relačního typu já“, což je „,pojetí sama sebe, které reflektuje vzájemnou provázanost všech věcí“ (Lužný 2004: 83). Takto je například péče o vlastní zdraví i péčí o zdraví kosmu. Ničení vlastního těla drogami, nezdravým potravinami a podobně, odpovídá ničení planety chemikáliemi a jiným odpadem. Lidské a ne-lidské je tak propojeno.

16 V rozhovorech jsme se často dostali $\mathrm{k}$ environmentálním tématům a $\mathrm{k}$ otázce vztahu $\mathrm{k}$ př́rodě, Zemi či ekologii. Mnozí se snaží přispět k ochraně prostředí tříděním odpadů, sbíráním odpadků v lese či používáním ekologických čistících prostředků a přírodní kosmetiky. Příroda je zde velmi ceněna jako místo k načerpání sil a navázání kontaktu se sebou samým či s prrírodními duchovními bytostmi. 
Jedna mladá žena ve Zlatém kličcku mi řekla, že si nechce hrát na spasitele světa, stará se proto zejména o sebe, což ale není sobectví, protože tak alespoň nepřesouvá zodpovědnost za své činy na někoho jiného. Pokud každý začne u sebe, bude se podle ní proměňovat celek.

Důraz na funkčnost jedince $\mathrm{v}$ rámci celku vyjádřila terapeutka Zlatého kličcku:

Já bych radši byla $\mathrm{v}$ práci $\mathrm{v}$ harmonii, nějakým doplňování se, upřednostňování týmu v celku, ne individualit. Individuality celek vytváŕí, ale nemusí si nic dokazovat. Nepotřebuju mít kolem sebe lidi, kteří potřebují dokazovat, že k něčemu jsou. To my víme všichni, že k něčemu jsme. Tak si do té role stoupni a žij tím. To mě zajímá.

Prožitek takového „relačního typu já“ mohou nabízet „rodinné konstelace“. Jedná se o „systémovou terapii“, při níž se vždy pracuje ve skupině osob - vybraný účastník sestavuje „konstelaci“. Zvolí si osoby jako zástupce členů své rodiny, včetně sebe samého, a postaví je na príslušná místa $\mathrm{v}$ prostoru, kam podle jeho vnitřního obrazu rodiny patří. Poté stranou pozoruje, co tito zástupci dělají a říkají. Jeden z účastníků popisuje, že on - jako zástupce cítil emoce jednotlivých členů rodiny, ačkoli se mu to zdálo neuvěřitelné:

Rodinné konstelace nejsou o tobě, ale o celém obrázku. Když tě terapeut postaví do konstelace a pritom to není tvoje úloha, zjistíš, jak to sedí i na ten tvưj problém. To mě dost překvapuje. Já jsem hrál, byl jsem postavený do konstelace a ř́kal si, jak budu jako jednat, vždyt' vůbec nemůžu vědět, jak člověku, kterému to hraju, můžu pomoct, když budu sám sebou. A najednou to jede. Stojím tam a reaguju spontánně. Konstelace jsou docela nářez, protože vůbec nechápeš, jak se začne všechno dít, když tam hraješ, začne to ovlivňovat tvůj život.

Konstelace tedy podle slov těch, kteří je praktikují, přinášejí zážitek sounáležitosti a propojení - např́ílad s vlastní rodinou. Svou současnou životní situaci umíst’ují účastníci konstelací do kontextu rodinných osudů. Př́iběhy předků, které nikdy neviděli, se zde za vedení terapeuta určitým způsobem zpř́tomňují. $\mathrm{V}$ průběhu konstelací jsem zaznamenala mnoho emocionálně vypjatých momentů, kdy přítomní brečí, křičí na sebe a podobně. Někdy dochází k odhalení něčeho zapomenutého nebo potlačovaného, např́íklad informace, že otcem je někdo jiný, než se myslí. Přítomní vypovídají, že pocitují solidaritu s hlavním aktérem konstelace už proto, že všichni tyto pocity důvěrně znají ze svého života, i když se může jednat o jinou událost či situaci. V průběhu terapie „diváci“ sedí na zemi po okrajích místnosti a pozorují průběh terapie. Po jejím ukončení se shlukují do skupinek, povídají si a utvářejí společně význam toho, co se dělo.

\section{Tělesnost v New Age: „Jemnohmotnost“ těla a intersubjektivita}

Uvědomění si svého těla a jeho re-evaluace je v prostředí New Age „součástí nově pojaté sebe-reflexivity a nového způsobu konstrukce vlastní identity“ (Václavík 2006: 250). Lidé ze Zlatého kličku pokládají tělo za prostředek k odstranění bloků (nejrůznější techniky zaměřené na práci s bloky na tělesné úrovni mají způsobovat i psychickou úlevu), navázání kontaktu se sebou samým (např́klad při soustředění se na vlastní pocity při cvičení), k dosažení harmonie těla, duše a ducha a stavu zdraví (například prostřednictvím určité diety). Tělo je podle nich ukazatelem vlastních postojů $\mathrm{k}$ sobě samému (i symptomy nemocí mají podle návštěvníků 
centra svou „,̌̌č““ a vypovídají o postojích nemocného). Sebekultivační tělesné techniky mají být cestou k objevení vlastních skrytých schopností a sil, mají sloužit k jejich aktivaci či rozvoji. Ve Zlatém klíčku se terapeuti snaží napravovat nejrůznější škodlivé návyky těla. To, co má být $\mathrm{v}$ procesu transformace zejména efektivní, jsou terapeutické praktiky.

Tělo zde není nahliženo jako pouhý fyzický objekt. Představa těla jako materiálního objektu pramení už z karteziánského oddělení těla a mysli (Scheper-Hughes, Lock 1987). Tělo, tak je je zažíváno, zahrnuje ale i emoce, zkušenosti, intuici a podobně. Např́ílad německý jazyk umožňuje jemnější distinkce vystihnout: „Körper“, ekvivalent k anglickému „body“, znamená zpředmětněné tělo a „Leib“ odkazuje k živému tělu s pocity, vjemy, emocemi a zkušenostmi (Scott 1999).

Místo dualismu těla a mysli najdeme v New Age „sofistikovanější modely propojenosti““ (Bloch 1988: 50). A jak se tyto principy odráží v podobě terapeutických praktik? Různé techniky si kladou za cíl primárně působit bud' na úrovni tělesné, duševní nebo duchovní, avšak efekt - tedy změna - se má postupně projevit na úrovních všech. Transformace se v pojetí návštěvníků centra šiří z roviny ducha (nevědomého) přes proces zvědomování až $\mathrm{k}$ činům ${ }^{17}$ - reálným krokům ve vlastním životě. Terapeuti mohou být zaměřni na odlišné úrovně, a z toho důvodu někdy spolupracují nebo doporučují svým klientům i terapii i někoho jiného, pokud se domnívají, že by jim to prospělo. Většinou různé techniky sami kombinují.

Pojmy „tělo“, „duše“ a „duch“ se všemi svými konotacemi mohou evokovat tři oddělené substance - představu duše, která v těle jen „sídliı“. V prostředí Zlatého klíčku je užíván koncept několikerých těl. Jednotlivá těla se prolínají a liší se jen jemností hmoty, která je tvoří. Terapeutka, která pracuje s konceptem tří těl, hovoří o semináŕi, kde se tato těla „čistí‘:

Tělo máme fyzické hrubohmotné a potom jemnější hmotné. Čím je jemnější, tím míñ je hmoty. Tělní tekutiny jsou jemnější formy, jemnější těla, to už není hrubá hmota. Takhle to jde dál do psychických těl, to již $\mathrm{s}$ hmotou nemá nic společného, ale je potřeba ho zrovna tak očištovat a provětrávat jako hrubou hmotu. Tak, jak máme hrubé fyzické toxiny, máme i psychické a duchovní toxiny.

Tato negace oddělení těla, mysli a ducha předpokládá radikálně odlišný typ subjektu než najdeme u ortodoxní medicíny. Jemnohmotné tělo znamená rozšíření vlastního nitra za viditelné formy a implikuje radikální blízkost. Idea jemnohmotného těla sobě obsahuje de-individualizující impuls pro svou radikální nehmotnost: jedinec je propojený se širším okolím (Johnston, Barcan 2006).

Každý člověk ve svém dětském věku postupně formuje obraz o svém vlastním těle. Merleau-Ponty (1964) zavádí pro tento obraz pojem tělesný obraz (image du corps). Obraz, který přesahuje momentální vjemy a trvá $\mathrm{v}$ čase, označuje jako zvykové tělo (corps habituel). To zahrnuje „potenciál, dovednosti a schopnosti individuálního lidského těla“ (Kopf 2001: 51).

Young (2002) píše o „paměti rodiny“ obsažené v každém těle: je to jakási materializace „duchü“ vlastních předků, kdy jsou jejich těla začleněna do vlastního „body image“. Podobně P. Bourdieu zavedl pojem hexis pro vzorce gest, držení těla, postojů a podobně, které dítě

17 Terapeutky používají formulaci „informace se dostane až do těla“ - je prožívána jako přirozená součást vlastních zvyků a způsobů reagování na určité situace. 
(pokud pozorně sleduje jednání ostatních lidí a nevědomě ho napodobuje) přejímá od rodičů (Young 2002).

Mauss také obrací pozornost $\mathrm{k}$ nediskurzivním praktikám, které tělo utvářejí a př́mo na něj působí. To, co často považujeme za čistě biologickou či fyziologickou dovednost, je ve skutečnosti něco, co se člověk musí v průběhu života naučit. Odlišnosti mezi pohlavími, odlišnosti věkové a kulturní se mohou odrazit $\mathrm{v}$ odlišných fyzických schopnostech těl: lidé jsou učeni různými způsoby svá těla kontrolovat podle přijímaných norem způsobů chování. Takové trénování těla ale může probíhat naprosto nevědomě a po dlouhé roky, takže odnaučení těchto technik není jednoduché. Mauss tuto „vtělenou kulturu“ nazýval „habitem“. Habity se liší v závislosti na podobě společnosti, jejích dobrých mravech, módách (Bowie 2006). Tělo v tomto př́stupu můžeme vnímat jako „soustavu ztělesněných schopností a kompetencí“ (Hamar 2006: 21). Kulturní dimenze je v těle př́tomná, protože: „Tělo znehybněné v meditaci, tančící v extázi či celý den usazené $\mathrm{v}$ disciplinované pozici nad posvátnou knihou je tělo utvořené kulturou.“ (Hamar 2006: 22) Sociální, psychologické a biologické jsou nerozlučně promíchány. Tělesnost (zkušenost vlastní fyzičnosti zevnitř) není před kulturou, i ona má svou historii (Mol 2002).

Klienti terapeutek Zlatého kličku tyto sociologické náhledy na tělesnost (samozrejmě) neznají. Tyto koncepce uvádím, protože jsou, podle mého názoru, z mnoha dalších pojetí nejblíže modelu tělesnosti užívaném v tomto centru. Pojetí tělesnosti jako vtělené historie nám může přiblížit způsob, kterým se návštěvníci centra ke svým tělům vztahují. Korekce nezdravých modů fungování těla ve Zlatém kličku má spočívat ve vytváření nových návyků: nových způsobů držení těla, pohybu, nového vnímání vlastního těla (vlastního tělesného obrazu).

Návštěvníci centra $\mathrm{v}$ rozhovorech o technikách, se kterými měli zkušenost, vypovídali, že zkušenosti, emoce, zvyky, způsoby myšlení jsou zapsány do jejich těla. Každý proto své tělo jinak zažívá, jiným způsobem vnímá energie a podobně. Jde jim o to učinit tento „habitus" těla, který může souviset s navyklými způsoby myšlení a jednání vytvořenými v interakci s okolím, vědomým. Může jít o odnaučování zvyku povrchního dýchání - prvním krokem je reflexe: „Obrat'te pozornost na svůj dech“ (archandělská meditace). Př́i pomalé chůzi po chodbě a po schodech si lidé mají uvědomit, jak se vlastně pohybují, co se děje s rameny a kyčlemi, jak s tělem zachází. Cílem všech těchto cvičení je rozvíjet uvědomění těla: „Tak si stoupněte pohodlně, zavřete oči a navnímejte si tělo. Já u toho budu mluvit a vy si uvědomujte, jak jste schopni vnímat sami sebe, když máte v okolí nějaký hluk,“ a neustálých otázek: „Představujte si, jak energie proudí, po přední straně těla dolů a vzadu nahoru, jazyk je na horním patře. Tak, máte navnímáno, jak energie teče?“

„Zvykové tělo“, „habitus“ či „tělesný obraz“ je tím, co je prostřednictvím terapie zkoumáno, zvědomováno a proměňováno. Působení na tělo, duši nebo ducha za účelem odstranění problémů klienta bývá někdy nazýváno „odblokováním“, tedy odstraněním bloků. $\mathrm{V}$ rodinných konstelacích má dojít ke změně negativních vzorců myšlení, které si klient nese ze své původní rodiny. Bachovy esence ${ }^{18}$ mají kladně působit na emocionálními stavy ome-

18 Terapie založená na třiceti osmi květinových esencích. Má pomoci získat emocionální rovnováhu. Esence se mísí s vodou či alkoholem, a tak se připraví kapky, které se aplikují ústně. Vhodná esence je vybrána např́iklad na základě rozhovoru s terapeutkou, karet (orákula) nebo kineziologického testu. 
zující jeho rozvoj. Při kraniosakrálním ošetření odstraňuje terapeutka podle svých slov blokády a narušení kraniosakrálního rytmu vzniklé fyzickým způsobem (úrazy, operace, léky a drogy, zátěžové vlivy na držení těla...), nebo psychickými šoky a traumaty. Cvičení má sloužit k uvolnění blokủ bránícím volnému toku energie: „Když to převedeme na energii, stačí jeden ucpaný kloub a už neproudí tak, jak má. S těmi informacemi je to stejné, musí být čisto.“ Vtělená historie se tak stává reflektovanou.

\section{Závěr}

Cílem stati bylo přibližit spiritualitu New Age prostřednictvím př́ípadové studie o brněnském centru Zlatý kliček. Šlo mi o to představit svět terapeutické kultury z pohledu terapeutů a jejich klientů a ukázat, jaký význam dávají tito lidé svým interakcím $\mathrm{s}$ okolím a jak v průběhu terapeutického procesu dochází k rekonstrukci identit. „Pohled zevnitř“, který bere vážně výpovědi New Age praktikujících, považuji za první krok k překonání určitých zjednodušujících popisů této religiozity. Ty se s lehkou ironií zaměřují zejména na její komerční stránky, ${ }^{19}$ líčí př́islušníky New Age jako individuální konzumenty nabízených služeb, ${ }^{20}$ přičemž opomíjí intersubjektivní aspekt a tendence $\mathrm{k}$ vytváření komunity.

Sebepojetí jako explicitní vyprávění o sobě samém, které zahrnuje interpretaci vlastní historie, je v průběhu terapie proměňováno. Cílem praktik ve Zlatém klíčku má být „osvobození se“ od naučených způsobů myšlení o sobě samém. Je zde zdůrazňováno, že důležitost jedince spočívá zejména $\mathrm{v}$ jeho vztahu $\mathrm{k}$ celku, $\mathrm{v}$ jeho postavení $\mathrm{v}$ systému rodinných, pracovních či širších společenských vztahů. Terapie mu má pomoci najít vlastní „poslání“ - zjistit, jaké místo v tomto celku zaujímá a čím tomuto celku může přispět. Mé pozorování odpovídá tomu, co popisuje Maffesoli: socialita může mít formu ,ztráty vlastního těla $\mathrm{v}$ těle kolektivním“ (Maffesoli 1994: 25). Tak je tomu u skupinových terapeutických praktik navozujících stav „extáze“. U individuálních terapií má léčení jako korekce vlastní historie zahrnovat jako významnou součást i vztahy daného člověka s okolím - současné rodinné př́slušníky, předky, spolupracovníky a podobně.

Nový pohled na svět nebo sebe sama musí být vyjednáván v komunitě lidí, kteří nejsou jen náhodnými známostmi, ale scházejí se i mimo centrum. Terapeuti dlouhodobě spolupracují a podobně. ${ }^{21}$ Terapie nemá přinést jen soukromý pocit uspokojení; hranice privátní-soukromý

19 Tito autoři si všímají zejména vstupu obchodních vztahů do náboženské oblasti. Nešpor svou kapitolu o spiritualitě uzavírá: „Česká populace se tak stává jedním z nejlepších případů, potvrzujících heslo 'jsem to, co kupuji', což vede k situaci, kdy se konzumerismus v podstatě stává novým lidovým 'náboženstvím'“ (Nešpor 2004: 30). Domnívám se, že líčení New Age a hnutí lidských potencí jako „duchovního supermarketu“ (Lyon 2002), „nahlížení do výkladů různých církví a nakupování“ (Lyon 2002), „komercionalizovaných podob ,posvátna““ nebo „tržní spirituality“ (Nešpor 2004: 35) by nemělo vést ke konotacím, které by ho redukovaly na pouhou komerční záležitost.

20 Podle Lužného jsou témata léčení a osobního rozvoje komercionalizována. Spiritualita New Age a hnutí lidských potencí jsou ,výrazem stoupající individualizace života moderních společností, která se odráží i v rostoucí popularitě psychologie. Právě proto dochází k psychologizaci náboženství či spiritualizaci psychologie“ (Lužný 2004: 66).

21 To je v kontrastu s tím, co píše např́iklad o New Age terapeutické kultuře v USA Tucker (2004). 
přestává v jejím kontextu dávat smysl. Propojenost vlastního já s okolím souvisí také $\mathrm{s}$ konceptem „,jemnohmotných těl“, která zasahují za hranice dané „kůži““ a implikují intenzivní interakci s okolím. Tělo v tomto pojetí má také svou pamět', přičemž se opět jedná o historii rodinnou, př́padně historii kultury, ve které člověk žije.

\section{Literatura}

ANDERSON, Benedict. Pomyslná společenství. In HROCH, M. (ed.) Pohledy na národ a nacionalismus. 1. vyd. Praha : Slon, 2003. 451 s. ISBN 80-86429-20-2.

BERGER, Peter L. ; LUCKMANN, Thomas. Sociální konstrukce reality. 1. vyd. Brno : CDK, 2001. 216 s. ISBN 80-85959-46-1.

BLOCH, Jon P. New Spirituality, self, and belonging: How New-Agers and Neo-Pagans talk about themselves. Westport : Preager, 1988. 136 s. ISBN 0-27595-957-0.

BOWIE, Fiona. The anthropology of religion: an introduction. Oxford : Blackwell, 2006. 332 s. ISBN 1-405-12105-X.

DAVIE, Grace. From Believing without Belonging to Vicarious Religion. In POLLACK, D., OLSON, D. V. A. (eds.) The Role of Religion in Modern Societies. New York : Routledge, 2007. 296 s. ISBN 978-0-415-39704-9.

DOLEŽALOVÁ, Hana. Tělo a nemoc jako zdroje identity - prípadová studie o Zlatém kličku - „,centru zdraví a harmonie“. [Magisterská diplomová práce]. Brno : Fakulta sociálních studií, 2007.

GEERTZ, Clifford. Interpretace kultur. 1. vyd. Praha : Slon, 2000. 565 s. ISBN 80-85850-89-3.

GIDDENS, Anthony. Modernity and Self-Identity. 1. vyd. Cambridge : Polity Press, 1991. 264 s. ISBN 0-80471-944-6.

HAMAR, Eleonora. Náboženství a tělo. Teoretické perspektivy v diskurzu religionistiky. In DOLEŽALOVÁ, I., HAMAR, E., BĚLKA, L. (eds.) Náboženství a tělo. 1. vyd. Praha : Malvern, 2006. 272 s. ISBN 80-210-4115-3.

HANEGRAAFF, Wouter J. New Age Religion and Western Culture - Esoterism in the Mirror of Secular Thought. Leiden : Brill, 1996. 580 s. ISBN 9-00410-696-0.

HANEGRAAFF, Wouter J. New Age Spiritualities as Secular Religion: a Historian's Perspective. Social Compass, 1999, č. 2, s. 145-160. ISSN 0037-7686.

HEELAS, Paul. The New Age in Cultural Context: the Premodern, the Modern and the Postmodern. Religion, 1993, č. 2, s. 103-116, ISSN 0048-721X.

HEELAS, Paul. The New Age Movement. The Celebration of the Self and the Sacralization of Modernity. Oxford : Blackwell, 1996. 288 s. ISBN 0-63119-332-4.

JOHNSTON, Jay ; BARCAN, Ruth. Subtle transformations. Imagining the body in alternative health practises. International Journal of Cultural Studies, 2006, č. 1, s. 25-44. ISSN 1367-8779.

KONOPÁSEK, Zdeněk. Aby myšlení bylo vidět: Nad novou verzí programu ATLAS/ti. Biograf, 2005, č. 37, s. 89-109. ISSN 1211-5770.

KOPF, Gereon. Beyond Personal Identity: Dougen, Nishida, and a Phenomenology of No-Self. 1. vyd. Richmond : Routledge, 2001. 298 s. ISBN 0-70071-217-8. 
LUŽNÝ, Dušan. Nová náboženská hnutí. 1. vyd. Brno : Masarykova univerzita, 1997. $181 \mathrm{~s}$. ISBN 80-2101-645-0.

LUŽNÝ, Dušan. Hledání ztracené jednoty: Průniky nových náboženství a ekologie. 1. vyd. Brno: Masarykova univerzita, 2004. 107 s. ISBN 80-2103-492-0.

LYON, David. A Bit of Circus: Notes on Postmodernity and New Age. Religion, 1993, č. 2, s. 117-126. ISSN 0048-721X.

LYON, David. Ježíš v Disneylandu. Náboženství v postmoderní době. Praha : Mladá fronta, 2002. 272 s. ISBN 80-204-0941-6.

MACLEAN, Jason R. Book Review: Maffesoli, Michel. The Contemplation of the World: Figures of Community Style (1997). Critical Sociology, 2000, č. 1-2, s. 166-170. ISSN 0896-9205.

MAFFESOLI, Michel. Sociologie jako poznání sociality. S-Obzor, 1994, č. 1, s. 23-28. ISSN 1210-6089.

MAFFESOLI, Michel. The Time of the Tribes. The Decline of Individualism in Mass Society. 1. vyd. London, Thousand Oaks, New Delhi : Sage Publications, 1996. 192 s. ISBN 0-80398-474-X.

MAFFESOLI, Michel. O nomádství. Praha : Prostor, 2002. 270 s. ISBN 80-7260-069-9.

MERLEAU-PONTY, Maurice. The Primacy of Perception: and Other Essays on Phenomenology, Psychology, the Philosophy of Art, History and Politics. Evanston : Northwestern University Press, 1964. 228 s. ISBN 0-81010-164-5.

MOL, Annemarie. The Body Multiple: Ontology in Medical Practice. Durham : Duke University Press, 2002. 196 s. ISBN 0-82232-917-4.

NEŠPOR, Zdeněk R. Ústřední vývojové trendy současné české religiozity. In NEŠPOR, Z. R. (ed.) Sociologické studie: Jaká víra? Současná česká religiozita/spiritualita v pohledu kvalitativní sociologie náboženství. 1. vyd. Praha : Sociologický ústav Akademie věd ČR. 2004, s. 21-37. ISBN 80-7330-061-3.

NIETZSCHE, Friedrich. Zrození tragédie. 1. vyd. Praha : Nakladatelství Aloise Srdce, 1923. $160 \mathrm{~s}$.

OZAWA-DE SILVA, Chikako. Beyond the Body/Mind? Japanese Contemporary Thinkers on Alternative Sociologies of the Body. Body \& Society, 2002, č. 2, s. 21-38. ISSN 1357-034X.

SCOTT, Anne L. Paradoxes of Holism: Some Problems in Developing an Antioppressive Medical Practice. Health, 1999, č. 2, s. 131-149. ISSN 1210-7778.

SCHEPER-HUGHES, Nancy ; LOCK, Margaret. The mindful body: a prolegomenon to future work in medical anthropology. Medical Anthropology Quarterly, 1987, č. 1, s. 6-41. ISSN 0745-5194.

SZALÓ, Csaba. Sociologie formování sociálních identit. In SZALÓ, C., NOSÁL I. (eds.) Mozaika v re-konstrukci. Formování sociálních identit v současné středni Evropě. Brno : Mezinárodní politologický ústav, 2003, s. 13-37. ISBN 80-210-3306-1.

TUCKER, James. New Age religion and the cult of self. Society, 2002, č. 2, s. 46-51. ISSN 0147-2011.

TUCKER, James. A Church of One's Own: The Social and the Supernatural in New Age Religion. Paper presented at the annual meeting of the American Sociological Association, 
Hilton San Francisco \& Renaissance Parc 55 Hotel, San Francisco, CA [online]. 2004. [cit. 2008-13-06]. Dostupný z: http://www.allacademic.com/meta/p109317_index.html. TURNER, Bryan S. The Body and Society: Explorations in Social Theory. 2. vyd. London : Sage, 1996. 254 s. ISBN 0-80398-809-5.

VÁCLAVÍK, David. Obžerství, konzum a askeze v kontextu soudobé religiozity. In BUBÍK, T., FÁREK, M. (eds.) Náboženství a jídlo. 1. vyd. Pardubice : Univerzita Pardubice, 2005. s. 159-165. ISBN 8071948004.

VÁCLAVÍK, David. Tělo jako chrám. Cesty a podoby revalvace těla v kontextu New Age. In DOLEŽAlOVÁ, I., HAMAR, E., BĚLKA, L. (eds.) Náboženství a tělo. Praha : Malvern, 2006. s. 243-250. ISBN 80-2104-115-3.

VIRTUE, Doreen. Léčení s vílami. Kniha a 44 karet. Praha : Synergie, 2003. 64 s. ISBN 80-86099-86-5.

YORK, Michael. The Emerging Network: A Sociology of the New Age and Neo-Pagan Movements. Lanham : Roman \& Littlefield, 1995. 372 s. ISBN 0-847-68000-2.

YOUNG, Katharine. The Memory of the Flesh: The Family Body in Somatic Psychology. Body \& Society, 2002, č. 3, s. 25-47. ISSN 1357-034X.

\section{Internetové zdroje:}

http://www.zlatyklicek.cz/

http://sofielairena.sblog.cz/

\section{Autorka}

Hana Doležalová je doktorandkou na katedře sociologie Fakulty sociálních studií Masarykovy univerzity. Zabývá se tématy terapeutické kultury, necírkevní religiozity, tělesnosti a konstrukce identit.

Kontakt:65523@mail.muni.cz 